удк 378.147: 656.071.1

DOI 10.31494/2412-9208-2019-1-1-255-263

\title{
Competence of the English language teacher in the professional environment of future navigators
}

\section{Компетентність викладача англійської мови у професійному середовищі майбутніх судноводіїв}

\author{
Vasyl Zheliaskov, \\ Candidate of Pedagogical Sciences \\ Danube Institute of National \\ University \\ "Odessa Maritime Academy" \\ 9 Fanagoriiska St., Izmail, \\ Odessa region, 68601
}

Василь Желясков, кандидат педагогічних наук https://orcid.org/0000-0001-5698-6989 zhelvas72@gmail.com

\author{
Дунайський інститут \\ національного університету \\ "Одеська морська академія" \\ вул. Фанагорійська, 9, м. Ізмаїл, \\ Одеська область, 68601
}

Original manuscript received January 31, 2019

Revised manuscript accepted April 14, 2019

\begin{abstract}
The article is devoted to the analysis of competence of teacher in the professional studying. The special skills and abilities of foreign intercourse are required for professional activity of maritime specialists. The task of vocational education is not only the formation of professional knowledge, skills and abilities, but also the orientation to further enhancement of professional communication interaction, the development of communication skills to solve professional problems. For the professional activity of future maritime specialists, the communication skills become of special importance. The sphere of professional communication interaction of navigators according to the requirements of International Convention include the use of English in the transmission and reception of information, planning and conducting location, the use of radar for the safety of navigation, emergency operations, personnel, etc. In the process of organization model of professional English studying, specification of maritime industry and safety of sailing in international navy space should be taken into account. In the article the author proves the importance of learning the basics of maritime speciality and professional terminology by the teachers of English. Accordingly, the teaching methods of this course should be as close as possible to the specifics of the professional activity, its lexical, syntactical and morphological content, that are characteristic of the professional activity of future navigators. Some approaches to solving the problem has been offered: to use materials in English classes based on the concepts of navy specialty, since teachers are often mistakenly believe that students are sufficiently familiar with the basics of their profession; to create professional situations in English classes in which students could use the acquired theoretical knowledge to solve practical problems; to use the information which is known to students, but presented in another way; to concentrate students' attention on the instructions and explanations of practical use of the language, but based on the methodology of the specialty.

Keywords: professional English studying, context learning, teacher, future navigators, teaching in a team, approach to studying.


Вступ. Основна риса професійно орієнтованого навчання англійської мови (комунікативної взаємодії майбутніх судноводіїв) полягає в тому, що курс будується на основі конкретних професійно значущих цілей і завдань студентів-моряків, що відповідає методиці підбору й організації тематичного матеріалу, а також розвитку відповідних навичок і вмінь. Професійно орієнтоване навчання іноземної мови застосовується при підготовці фахівців і підвищенні кваліфікації. У першому випадку студентами закладу вищої освіти (3ВО), не мати чіткого уявлення про навички і вміння майбутньої професійної діяльності, унаслідок чого вони повністю покладаються на викладача у виборі навчальних матеріалів, професійних тем, лексики, розвитку навичок професійного спілкування. Під час перепідготовки кадрів (на курсах підвищення кваліфікації, наприклад) слухачі легко орієнтуються і в специфічній тематиці, і в професійній лексиці. Вони мають уявлення про те, які саме навички спілкування для здійснення професійної комунікативної взаємодії необхідні, в першу чергу, при виконанні обов'язків судноводіїв. Завданням професійної освіти стає формування не тільки фрахових знань, умінь та навичок, а й орієнтації на подальше підвищення професійної комунікативної взаємодії, розвиток уміння спілкуватися для розв'язання фахових завдань. До сфери профеесійної комунікативної взаємодії фахівця морської галузі за вимогами Міжнародної Конвенції належать такі: використання англійської мови при передачі та прийомі інформації, планування і проведення переходу та визначення місцезнаходження, використання радіолокатора для забезпечення безпеки мореплавства, дії у надзвичайних ситуаціях, при отриманні сигналу про надзвичайну ситуацію, маневрування судна; нагляд за завантаженням, розміщенням, кріпленням, збереженням вантажу під час плавання; використання рятувальних засобів та пристроїв, надання першої медичної допомоги на суднах, безпека персоналу та судна та ін. Проте не кожен викладач-початківець має належний рівень підготовки до професійно орієнтованого викладання, зокрема у вищому морському навчальному закладі.

Методиці засвоєння термінологічної лексики студентів, які вивчають іноземні мови в технічних, морських, авіаційних, медичних, економічних, гуманітарних, військових та інших немовних 3ВО, присвячені дослідження В. Борщовецької, М. Бурлакова, О. Величка, Н. Говорової, Л. Зеленської, Г. Іткіса, О. Краснянської, В. Кудряшової, 3. Кузьменко, Р. Мар'ясової, В. Мурзової, Г. Пащенко, Н. Петрушевської, В. Півень, О. Розанова, Н. Саєнко, Н. Сайгушевої, С. Семенової, О. Тарасової, Г. Харлова, І. Чудінової, Р. Дей, Р. Холм, М. Джонак, І. Краковяк, П. Ур та ін.

Особливістю професійно орієнтованого навчання англійської мови $\epsilon$ те, що для кожної професійної галузі (судноплавство, авіація, економіка, медицина) або дисципліни (морська або повітряна навігація, політологія, менеджмент, і т. д.) може бути розроблено спеціальний курс англійської мови, характерний лише для них. Відповідно до цього 
методика викладання цього курсу повинна максимально відповідати специфіці спеціальності, тобто лексичне наповнення, а також формування навичок і вмінь, які $€$ необхідними для цієї професійної діяльності. Таким чином, структура курсу навчання англійської мови в кожному випадку буде різною. 3 огляду на це мета статті проаналізувати підходи до викладання англійської мови морської галузі та запропонувати методи створення навчального середовища для професійної комунікативної взаємодії майбутніх судноводіїв.

Методи та методики дослідження. У статті використано теоретичні методи дослідження педагогіки: аналіз наукової літератури, загальних і спеціальних праць з педагогіки та психології, підручників та методичних посібників з методики викладання англійської мови у закладах вищої освіти, зокрема технічного напряму, з метою висвітлення різних підходів, ідей, концепцій, понять до підготовки майбутніх судноводіїв до професійної комунікативної взаємодії.

Результати та дискусії. Характерною рисою професійно орієнтованого навчання англійської мови $€$ усвідомлена необхідність в опануванні нею з метою фахового спілкування, яка виникає в досить дорослих людей, що зазвичай володіють іноземною мовою на високому, середньому або, принаймні, елементарному рівні. Нині в Україні немає факультетів або відділень в університетах, де можна було б отримати підготовку із спеціалізації "Викладач англійської мови для спеціальних цілей”. Тому викладачами з професійно орієнтованого навчання англійської мови $є$ випускники фрілологічних фракультетів університетів і педагогічних 3ВО, які отримали базову лінгвістичну і педагогічну освіту, але не володіють навичками викладання іноземної мови в професійній сфері. Роль викладача англійської мови в професійно орієнтованому навчанні набагато більша, оскільки, крім основних навичок викладання загальної англійської мови, потрібно мати знання самого предмета (морська, медицина, гірська справа, авіація, міжнародні відносини і т. д.), професійної лексики й уявлення про комунікативні особливості цього фаху. Унаслідок відсутності такої підготовки, викладачі стикаються 3 багатьма проблемами, які М. Готті об'єднав у п'ять різних категорій (Gotti, 1984: 138):

1) психологічні (складність перекваліфікації викладача загальної англійської мови у викладача англійської мови для спеціальних цілей); текстів);

2) концептуальні (проблеми розуміння змісту професійних

3) лінгвістичні (незнання професійної лексики для засвоєння 3 боку студентів);

4) методичні (складність адаптації загальних методичних принципів і підходів до конкретної групи студентів, які часто є людьми досить зрілого віку);

5) організаційні (проблеми, що виникають при розробці програми або курсу навчання).

Приймаючи за основу першочергові завдання, що стоять перед 
конкретною групою учнів, Т. Хатчинсон і А. Вотерс (Hutchinson T., Waters A.) пропонують використовувати різні підходи до розробки курсу. Головним завданням першого підходу є вивчення мови (“language-centred”), другої опанування навичок ("skills-centred"), третьої - фрормування самого процесу навчання ("learning-centred") (Hutchinson \& Waters, 1996: 65). Ці підходи можуть чергуватися, взаємно доповнювати або плавно переходити з одного в інший. При цьому методика викладання англійської мови професійного спрямування, як і методика викладання загальної англійської мови, сприяє організації процесу навчання, основним принципом якого $є$ перенесення акценту з викладача як джерела знань, контролера результатів навчання на учнів або курсантів.

У науковій і методичній літературі часто виникає питання про те, наскільки компетентним має бути викладач англійської мови в спеціальності, якої навчаються його студенти. Щодо цього існують різні, інколи протилежні думки. По-перше, багато що залежить від рівня компетентності самих учнів: чи $€$ вони студентами-початківцями або досвідченими фахівцями, які не потребують ознайомлення з основами профресії. По-друге, слід ураховувати думку студентів про роль викладача іноземної мови: не кожний студент очікує, що на заняттях з англійської мови він вивчатиме лексику і граматику, сприйматиме інформацію із спеціальних предметів, які він вивчає паралельно з англійською мовою на більш глибокому рівні. П. Стрівенс (Strevens P.) дає такі рекомендації викладачам англійської мови в професійно орієнтованому навчанні (Strevens, 1988: 42):

1) вивчити навчальні матеріали за фахом;

2) вивчити мову спеціальності;

3) бути готовим до того, що студенти виправлятимуть помилки викладача (маються на увазі неточності в професійній сфері, а не в мові).

Для адаптації молодих викладачів англійської мови-початківців доцільно проводити цикл занять з ознайомлення з певним предметом. Крім того, участь у конференціях і обмін досвідом в асоціаціях викладачів англійської мови для фрахівців-представників різних професій допомагають в удосконаленні стилю і методів викладання, оригінальних підходів до вирішення складних завдань.

Безумовно, викладачам англійської мови слід прагнути до вивчення основ спеціальності і базової професійної лексики. Тому бувають випадки, коли викладачі іноземної мови, використовуючи на заняттях професійний матеріал, настільки опановують предмет, що в змозі самі скласти іспит з певної галузі на задовільному рівні. Дослідження, проведене Л. Селінкером (Selinker L.), показало, що часто відсутність базових знань і нерозуміння концептуальних основ спеціальності веде до спотворення сенсу при перекладі та інших видах роботи з текстом при дотриманні всіх лінгвістичних норм англійської мови (Selinker, 1979: 190). Розвиваючи цю думку, пропонується декілька підходів до вирішення проблеми в цілому:

1) використовувати на заняттях з англійської мови матеріали, що 
ознайомлюють $з$ базовими поняттями спеціальності, оскільки дуже часто викладачі помилково вважають, що студенти достатньо обізнані 3 азами обраної професії;

2) створювати професійні ситуації на заняттях з англійської мови, в яких курсанти могли б використовувати отримані теоретичні знання для вирішення практичних завдань;

3) використовувати інформацію, відому курсантам, але представлену з іншої позиції;

4) сконцентрувати увагу курсантів на інструкціях і поясненнях викладача або підручника як прикладі практичного використання мови, але спираючись на методику спеціальності.

Одним із шляхів, за допомогою якого викладач може мати успіх у цьому напрямі, $\epsilon$ "викладання в команді" ("team teaching"), тобто співпраця 3 двома або більше фахівцями - викладача англійської мови з викладачем фрахових дисциплін. Такий вид співпраці стає все більш популярним. Перевагами "викладання в команді" $є$ такі (Dudley-Evans, 1983: 25):

1) студент має можливість оцінити свої успіхи 3 позиції академічних вимог;

2) викладач може визначити труднощі, 3 якими стикаються курсанти в процесі навчання основного курсу, і зробити висновок, наскільки ефективно проходить процес комунікації на заняттях;

3) у викладача $є$ зворотний зв'язок із курсантами, в результаті якого він може переконатися, наскільки добре його розуміють курсанти.

Слід зазначити, що ці переваги здебільшого відносяться до викладання спеціальних предметів англійською мовою, що нехарактерно для українських ЗВО. Проте, в закладах морської спрямованості досить поширена практика викладання лекцій англійською мовою, оскільки вона $€$ однією із офріційних мов IMO для професійної комунікативної взаємодії майбутніх судноводіїв за міжнародними стандартами.

Контекстне навчання - один із напрямів педагогічних технологій, що здобув популярність в останні роки. У 90-х рр. минулого століття А. Вербицький запропонував викладання загальних дисциплін у контексті майбутньої професійної діяльності (Вербицький, 1999). Водночас було зазначено, що поряд із традиційною методикою потрібно використовувати методи активного навчання, підходити комплексно до освітнього процесу. Контекстне навчання проектують з урахуванням мети, змісту, принципів навчання, умов педагогічного процесу, контингенту курсантів, професійної підготовки та індивідуальних доробок викладача. Контекст - це те, що аналізують як ціле, яке зв'язує й пояснює певні явища, фракти (Бусел, 2005: 567).

Провадження професійної діяльності судноводіїв англійською мовою може створювати ситуації, що породжують різні ступені напруженості. Апогей напруженості в цих ситуаціях досягається в процесі реалізації розробки, що завжди пов'язана з професійним ризиком та 3 ухваленням оперативних рішень. Штучне створення особливих умов професійної діяльності, за яких час поєднується з високою інтенсивністю 
Серія: Педагогічні науки. - Вип.1. - Бердянськ : БДПУ, 2019. - 406 с.

праці і низкою непередбачуваних обставин та містить фактор екстремальності у вигляді підвищеної психічної напруженості, вирізняється необхідністю негайного свідомого реагування й дії. Особливі та екстремальні обставини в професії судноводіїв виникають, зокрема, у разі незапланованої появи несприятливих погодних умов, відмови приладів тощо. 3 огляду на це доцільно запропонувати контекстне навчання, пов'язане з реальними ситуаціями в морі, у стандартних і нестандартних ситуаціях. Контекстні методи можуть бути використані в межах різних навчальних дисциплін англійською мовою. Позитивний навчальний аспект методу умотивований тим, що такий вид роботи може бути виконаний у групах, у форматі парної роботи, індивідуально. Проте ми рекомендуємо контекстні методи і завдання досвідченим курсантам 45 курсу, які вже мають достатньо знань із професійно орієнтованих дисциплін. Це дає підстави стверджувати, що курсанти, залучені до виконання контекстних завдань англійською мовою, одночасно вдосконалюють знання 3 професійно орієнтованих дисциплін та 3 англійської мови. Таким чином, створюється англомовна атмосфера та активізуються навички з технічної англійської мови.

Розвиваючи ідею контекстного навчання стосовно викладання професійно орієнтованих дисциплін економічного спрямування, Л. Курбан наголошує на важливості взаємодії викладачів мовних і професійних кафедр на всіх етапах навчання. Поетапне формування професійної компетентності ґрунтується на міжпредметній інтеграції профільних дисциплін. Отже, кафедра української та іноземних мов має працювати в контексті з профільними кафедрами міжнародної економіки, маркетингу й економічної теорії (Курбан, 2012: 267]. Доцільно зазначити, що така співпраця збагачує знання не тільки студентів, а й викладачів, які перебувають у тісному взаємозв'язку: фахівці-фрілологи стають обізнані 3 економічними дисциплінами, а викладачі професійних дисциплін мають змогу навчитися іноземної мови.

Реалізація контекстного навчання судноводіїв відбувалася наступним чином. У руслі нашого дослідження "контекст" витлумачений у двох площинах: 1) на макрорівні як інтегративна єдність у викладанні професійно орієнтованих дисциплін в англомовному контексті; 2) на мікрорівні як конкретна морська ситуація, що має причину й наслідок. Відповідно до першого підходу викладання професійних дисциплін англійською мовою контекст задається навчальними планами та програмами цих дисциплін. Викладачів-фрілологів і викладачів професійних дисциплін із суміжних кафедр організовують у групи по 3-4 особи з подальшою роботою в команді. Їхня діяльність відбувається за такою схемою:

1) складання курсу лекцій українською мовою;

2) складання термінологічного словника-довідника, скорочень морського контексту;

3) переклад навчального матеріалу англійською мовою, дослідження професійних джерел викладачем-філологом із дисципліни, 
яку він перекладає, та розроблення додаткових завдань;

4) аудіозапис термінологічного словника-довідника з правильною англійською вимовою;

5) спільна позааудиторна діяльність - розроблення навчальнометодичного супроводу викладачем-філологом і викладачем професійної дисципліни.

У руслі другого підходу зауважимо, що з'ясування лінгвістичних особливостей морської англійської лексики довело факт відсутності в морських термінах багатозначності; їм притаманна стислість і лаконічність. Морська терміносистема $€$ елементом загальної лексичної системи, тому синонімічні слова та словосполучення англійської мови слід використовувати обережно, у контексті конкретної ситуації. Наприклад, слова "wet" (мокрий) та "damp" (вологий) - синоніми, але в морському контексті вони мають різне значення, що може вплинути на точність текстів із судноплавства. Трапляються також слова, які мають схоже звучання чи подібне написання. Наприклад, "асcеpt" / "except", "cattle" / "kettle", "derives" / "drives", "depleted" / "deleted”, "arise" / "erase". Ці слова можуть функціювати в морському контексті в різних значеннях.

Таким чином, розвиваючи ідею контекстного навчання, ми активізуємо мотиваційний компонент навчання курсантів, що призводить до отримання більш високого рівня знань, умінь й навичок для професійної комунікативної взаємодії судноводіїв.

Висновки. Отже, теоретичне обґрунтування різних підходів до підготовки майбутніх судноводіїв до професійної комунікативної взаємодії дозволило дійти висновку про постійне вдосконалення організації освітнього процесу у вищих морських навчальних закладах. Провідні педагоги всього світу перебувають у постійному пошуку шляхів більш швидкого й ефективного засвоєння знань у цьому напрямку. Який би підхід не вибрав викладач англійської мови, у будь-якому випадку від нього вимагається володіння певними знаннями конкретної професійної галузі, знайомство 3 комплексом навичок, необхідних для здійснення професійної діяльності, бажання вдосконалити процес викладання англійської мови на матеріалі фахових дисциплін. Педагогічний процес постійно збагачується новими шляхами оперування отриманою інформацією, творчим підходом до розв'язання питань науки з акцентом на індивідуалізацію освітніх програм. Основні тенденції вдосконалення освітніх технологій характеризуються переходом від орієнтування на усередненого студента до індивідуалізованих програм навчання. У таких умовах викладачеві потрібно використовувати сучасні інноваційні технології, ідеї, напрямки. Перспективи подальших пошуків у напрямі дослідження полягають у конкретизації та практичній імплементації методів підвищення кваліфікації викладачів англійської мови у вищих морських навчальних закладах.

\section{Література}

1.Великий тлумачний словник сучасної української мови (з дод. і допов.) / упоряд. і голов. ред. В.Т. Бусел. - Ірпінь: ВТФ “Перун”, 2005. - 1728 с.

2.Вербицкий А. А. Новая образовательная парадигма и контекстное 
обучение: монография. / А. А. Вербицкий. Москва: Исследовательский центр проблем качества подготовки специалистов, 1999. - 75 с.

3.Курбан Л. П. Проблеми викладання іноземної мови в економічному ВНЗ. Экономика Крыма. - Симферополь, 2012. - №2 (39). - С. 264-267.

4. Gotti M. How successful can an ESP course by a non-specialist teacher be? // Teaching and the teacher. Oxford: Modern English Publications, 1984. - P. 138-141

5. Dudley-Evans T. Towards team-teaching: A description of cooperation between language and subject teachers at Ngee Ann College. // Dudley-Evans T. Papers on Team teaching and Syllabus Design. Occasional Papers 27. - Singapore: SEAMEO Regional English Language Centre, 1983. - P.22-34.

6. Hutchinson T., Waters A. English for Specific Purposes. A learning-centred approach. Cambridge: Cambridge University Press, 1996. - 183p.

7. Selinker L. On the use of informants in discourse analysis and "Language for specialized purposes". //IRAL, vol. XVII, № 3. - London, 1979. - P. 189-215.

8. Strevens P. The Learner and Teacher of ESP. / ESP in the Classroom: Practice and Evaluation. Ed. D.Chamberlain \& R.J.Baumgardner // ELT Documents, 128. - Oxford: Oxford University Press, 1988. - P.39-44.

\section{References}

1.Busel, V. T. (2005). Velykyi tlumachnyi slovnyk suchasnoi ukrainskoi movy [Big Dictionary of contemporary Ukrainian language (with additional notes)]. Irpin: VTF «Perun» [in Ukrainian].

2.Verbytskyi, A. A. (1999). Novaia obrazovatelnaia paradyhma y kontekstnoe obuchenye: monohrafyia. [New educational paradigm and contextual learning: monograph]. Moskva: Yssledovatelskyi tsentr problem kachestva podhotovky spetsyalystov [in Russian].

3.Kurban, L. P. (2012). Problemy vykladannia inozemnoi movy $v$ ekonomichnomu VNZ. In Ekonomika Kryma. Symferopol, 2 (39), 264-267 [in Ukrainian].

4.Gotti, M. (1984). How successful can an ESP course by a non-specialist teacher be? Teaching and the teacher. Ed. S. Holden. The British Council 1984 Bologna Conference. Oxford: Modern English Publications, 138-141 [in English].

5. Dudley-Evans, T. (1983). Towards team-teaching: A description of cooperation between language and subject teachers at Ngee Ann College. Papers on Team teaching and Syllabus Design. Occasional Papers 27. Singapore: SEAMEO Regional English Language Centre, 22-34 [in English].

6. Hutchinson, T., Waters, A. (1996). English for Specific Purposes. A learningcentred approach. Cambridge: Cambridge University Press.

7.Selinker, L. (1979). On the use of informants in discourse analysis and "Language for specialized purposes". London, IRAL, vol. XVII (3), 189-215 [in English].

8. Strevens, P. (1988). The Learner and Teacher of ESP. ESP in the Classroom: Practice and Evaluation. Ed. D.Chamberlain \& R.J.Baumgardner. ELT Documents, 128. Oxford: Oxford University Press, 39-44 [in English].

\section{АНОТАЦІЯ}

Стаття присвячена аналізу компетентності викладача в професійно орієнтованому навчанні. Завданням професійної освіти стає фоормування не тільки фрахових знань, умінь та навичок, а й орієнтації на подальше підвищення профресійної комунікативної взаємодії, розвиток уміння спілкуватися для розв'язання фрахових завдань. Для профресійної діяльності морських фахівців особливого значення набувають навики і уміння іншомовного спілкування. До сфрери професійної комунікативної взаємодії фрахівця морської галузі за вимогами Міжнародної Конвенції належать такі: використання анелійської мови при 
передачі та прийомі інформації, планування $і$ проведення переходу та визначення місцезнаходження, використання радіолокатора для забезпечення безпеки мореплавства, дії в надзвичайних ситуаціях, безпека персоналу, судна та ін. При організації моделі профресійно орієнтованого навчання англійською мовою слід, перш за все, враховувати специфіку морської галузі та безпеку судноплавства у світовому морському просторі. У статmі автор доводить важливість того, що викладачам англійської мови слід досконало вивчити основи морської спеціальності і базову профресійну лексику. Відповідно до цього методика викладання цього курсу повинна максимально відповідати специфіці спеціальності, тобто лексичне наповнення, а також навички і уміння, які $\epsilon$ характерними для певної професійної діяльності. Розвиваючи цю думку, запропоновано декілька підходів до вирішення проблеми в цілому: використовувати на заняттях з англійської мови матеріали, що ознайомлюють з базовими поняттями спеціальності, оскільки дуже часто викладачі помилково вважають, що студенти в достатній міри обізнані з азами обраної профресії; створювати професійні ситуації на заняттях з англійської мови, в яких курсанти могли б використовувати отримані теоретичні знання для вирішення практичних завдань; використовувати інфрормацію, відому курсантам, але представлену з іншої позиції; сконцентрувати увагу курсантів на інструкціях і поясненнях викладача або підручника як прикладі практичного використання мови, але спираючись на методику спеціальності.

Ключові слова: профресійно орієнтоване навчання, контекстне навчання, викладач, майбутні судноводії, викладання в команді, підхід до навчання. 